\title{
MOLECULAR MARKER ASSISTED STUDIES ON GENETIC DIVERSITY IN BRASSICA SPECIES
}

Rohit Sharma*1, Sandeep Kumar ${ }^{2}$

${ }^{* 1,2}$ Department of Biotechnology, NIET, NIMS University, Jaipur, INDIA

\begin{abstract}
:
Genetic diversity of seven genotypes of Brassica campestris was evaluated by using RAPD primers. A total of 15 DNA bands were revealed wherein 11 polymorphic bands were observed. Highest polymorphism was showed by the primer OPA 7 (87.50\%) and lowest by the primer OPA 9 (57.14\%). Relatively higher genetic diversity was found among the collected individuals. A maximum similarity based on Jaccard coefficient was showed highest and lowest value (0.750) and (0.364) respectively. The UPGMA cluster analysis revealed three main group of clusters in which one group was found to be sub grouped and other two main groups were found to be divergent. Cluster analysis revealed distant relationship among all the cultivars used in this study. Based on our study, RAPD analysis proved to be a useful tool in assessing the genetic diversity of leafy Brassica germplasm. These results also proved that RAPD markers are highly suitable and efficient tool for genetic characterization of many plant species including oilseed rape and other species.
\end{abstract}

Keywords:

RAPD, polymorphism, Brassica campestris.

Cite This Article: Rohit Sharma, and Sandeep Kumar, "MOLECULAR MARKER ASSISTED STUDIES ON GENETIC DIVERSITY IN BRASSICA SPECIES" International Journal of Research-Granthaalayah, Vol. 3, No. 7(2015): 63-71.

\section{INTRODUCTION}

The genus Brassica belongs to the plant family Brassicaceae, and is among one of the most important crop cultivated in all parts of the world. It includes various important agronomical crops such as oilseed rape, cabbage, broccoli, cabbage, black mustard, and other leafy vegetables. Brassica mainly consists of six economically important species with great genetic and morphological diversity. The elementary species are Brassica nigra $(\mathrm{n}=8$, genome $\mathrm{B}), B$. oleracea $(\mathrm{n}=9$, genome $\mathrm{C})$ and $B$. rapa $(\mathrm{n}=10$, genome $\mathrm{A})$ which are believed to be secondarily balanced polyploid. Brassica carinata $(\mathrm{n}=17$, genome $\mathrm{BC})$, B. juncea $(\mathrm{n}=18$, genome $\mathrm{AB}$ ) and $B$. napus ( $\mathrm{n}=19$, genome $\mathrm{AC}$ ) each originated by hybridization and polyploidization of two different elementary species [1].B. campestrisand $B$. rapawere first described as two species by Linnaeus, with $B$. rapa being the turnip form and B. campestris, the wild weedy form. Later it was concluded that these were the same species and combined the taxa under the name B. rapa[2]. 


\section{INTERNATIONAL JOURNAL OF RESEARCH -GRANTHAALAYAH

Molecular markers can offer various advantages over conventional, phenotype-based alternatives as they are more stable and easily detectable in all tissues regardless of growth, differentiation, development, or defense status of the cell. Additionally, they are not confounded by environmental, pleiotropic or other effects [3-4]. Random amplified polymorphic DNA (RAPD) analysis is a PCR based molecular marker technique [5]. In this technique, single short oligonucleotide primer is arbitrarily selected to amplify set of DNA segments distributed randomly throughout the genome of interest. RAPD's were the first PCR-based molecular markers to be employed in genetic variation analyses. RAPD was the first to become available and it is most commonly and frequently used because of low cost and easy availability [67].RAPD markers play a significant role for the establishment of genetic relationships among the individuals. Genetic diversity plays an important role in crop improvement. It helps in the protection of our food supply by increasing the range of genes available to meet agricultural production challenges [8]. The evaluation of genetic diversity that presents in germplasm collections enhances the use of genetic variation in establishing a breeding program [9-10]. The studies based on identifying genetic relationships of Brassica species using different genetic markers. The previous research showed the use of RAPD markers to assess the diversity of Brassicas [11]. It was studied that the genetic relationships among Brassica species based on RAPD markers used to provide information of the suitability of selected parents for crossing and the improvement of breeds of Brassica species [12].

Therefore, an effort was made to characterize the collected seven cultivars of Brassica campestris applying RAPD markers to assess the relationships among cultivars. Since the genetic diversity of Brassica species of the country is not well intact, by identifying the promising genotypes can be used in future breeding projects.

\section{MATERIALS AND METHOD}

Seven Brassica cultivars viz., NRCHB-101, NRCDR-601, PB-80, PJK, RH-37, RH-80 and F-59 were obtained from seed corporation, Jaipur, India.

\section{DNA Isolation and Purification of DNA}

Fresh and young leaf samples were collected from seven days old seedlings. The total genomic DNA was extracted from the leaf samples using modified CTAB method [13]. $2 \mathrm{~g}$ of each leaves sample were grounded separately with the help of mortar-pestle. DNA isolation buffer ( $2 \mathrm{X}$ CTAB DNA Extraction Buffer - 100 mMTris, $20 \mathrm{mM}$ EDTA, $1.4 \mathrm{M} \mathrm{NaCl}, 2 \% \mathrm{CTAB}$ and 2 $\mu 1 / \mathrm{ml} \beta$-mercaptoethanol) and again grounded and homogenized mixture transferred in capped polypropylene tubes and incubated for $1 \mathrm{hr}$. at $60{ }^{0} \mathrm{C}$. One volume of chloroform: isoamyl alcohol (24:1) was added and mixed by inversion for 15 minutes and spun at 15,000 rpm for 15 minutes. Aqueous phase was transferred to another tube. Ice cold 2 volume of absolute alcohol was added to precipitate DNA. $20 \mathrm{ml}$ of $70 \%$ alcohol was added to the pellet of DNA and was kept for 20 minutes with gentle agitation. The pellet was collected by centrifugation at 5,000 rpm 


\section{INTERNATIONAL JOURNAL OF RESEARCH -GRANTHAALAYAH

for 5 minutes at $20^{\circ} \mathrm{C}$. The pellet was dried and then re-dissolved in $1000 \mu \mathrm{l}$ of TE buffer by keeping over night at $4{ }^{\circ} \mathrm{C}$ without agitation. RNA was removed by treating the sample with DNase free Rnaseand protein including RNase was removed by treating with chloroform: isoamyl alcohol (24:1). $2.5 \mu \mathrm{l}$ of RNase was added to $0.5 \mathrm{ml}$ of crude, DNA preparation ( $2.5 \mu \mathrm{l}$ of RNase $=25 \mu \mathrm{g}$ of RNase, so treatment was $50 \mu \mathrm{g} / \mathrm{ml}$ of DNA preparation) and mixed thoroughly and was incubated at $37^{\circ} \mathrm{C}$ for $1 \mathrm{hr}$. $0.4 \mathrm{ml}$ of chloroform: isoamyl alcohol (24:1) was added and mixed thoroughly for 15 minutes till an emulsion was formed and spun for 15 minutes at 15,000 rpm. Supernatant was taken and DNA was re-precipitated by adding double the quantity of absolute alcohol. To pellet the DNA, the tube was centrifuged for 5 minutes at 10,000 rpm. The pellet was washed with $70 \%$ alcohol and dried overnight. The DNA was re-dissolved in $500 \mu 1$ of TE buffer. The quantization of DNA was done by observing it at $260 \mathrm{~nm}$ and $280 \mathrm{~nm}$ wavelengths by using a UV- VIS spectrophotometer. Added $4 \mu \mathrm{l}$ of DNA mixed properly and record the absorbance (A) at both 260 and $280 \mathrm{~nm}$. Concentration of genomic DNA in each case was adjusted to $10 \mathrm{ng} / \mu \mathrm{L}$ indifferent aliquots and stored at $-20^{\circ} \mathrm{C}$ for use in PCR amplification.

\section{DNA amplification by PCR}

Two RAPDprimers OPA 7 and OPA 9 (obtained from 'Operon Technologies) were used for PCR amplification. PCR reactions were performed in a final volume of $20 \mu \mathrm{l}$ PCR amplification reactions were carried out in a total volume of $20 \mu \mathrm{l}$ containing $1 \mathrm{x}$ PCR buffer $(10 \mathrm{mM}$ TrisHCl $\mathrm{pH} 8.3,50 \mathrm{mM} \mathrm{KCl}), 2.0 \mathrm{mM} \mathrm{MgCl} 2,200 \mu \mathrm{M}$ each of dNTPs, $0.5 \mu \mathrm{M}$ of each primer, 1 unit TaqDNA polymerase (Bangalore Genei) and 20ng template DNA. The reaction was carried out in Corbett Thermal Cycler. Thermal cycler was programmed to 1 cycle of $5 \mathrm{~min}$ at $94^{\circ} \mathrm{C}$ as an initial hot start and strand separation step. This was followed by 35 cycles of 1 min at $94^{\circ} \mathrm{C}$ for denaturation, $1 \mathrm{~min}$ for annealing temperature mainly depends on the marker used $\left(55^{\circ} \mathrm{C}-65^{\circ} \mathrm{C}\right)$ and 2 min at $72^{\circ} \mathrm{C}$ elongation. Finally, 1 cycle of $7 \mathrm{~min}$ at $72^{\circ} \mathrm{C}$ was used for final extension. Amplified products were stored at $-20^{\circ} \mathrm{C}$ until further use. The reproducibility of the amplification products was checked twice for each primer.

\section{Electrophoresis of amplified products}

After amplification, a $10 \mu \mathrm{l}$ aliquot of the amplified PCR products was combined with $3 \mu$ of a loading buffer bromophenol blue and was analyzed on 1.5\% agarose gels in stained in 1xTBE buffer $(10 \mathrm{mM}$ Tris-Borate, $1 \mathrm{mM}$ EDTA)containing $0.5 \mu \mathrm{g}$ per $\mathrm{ml}$ of Ethidium bromide. After electrophoresis, the gels were documented under UV light.

\section{Scoring and data analysis}

Electrophoresis of PCR products on agarose gel produced many bands. The size of these bands was compared with the DNA ladder (size marker). The data was entered into a binary matrix as a discrete variable based on presence and absence of bands. Those presented bands were marked as 1 and the absented bands were scored as 0 . Genetic similarities between all the accessions of 


\section{INTERNATIONAL JOURNAL OF RESEARCH -GRANTHAALAYAH \\ A knowledge Repository}

Science

Brassica campestris were calculated according to Jaccard coefficient. A dendrogram was constructed to get genetic relationships among accessions. This was used to estimate genetic distance and to construct a UPGMA (Unweighted Pair Group Method of Arithmetic Means) dendrogram among populations using a computer program NTSYS pc version 2.02 [14].

\section{RESULTS AND DISCUSSION}

After studying the presence of diverse bands, a total 15 bands were produced by using 2 primers and among these 11 were polymorphic (Fig.1 and 2).Highest polymorphic rates were produced by the primer OPA7, which produced 7 polymorphic bands, whereas the lowest number of polymorphic bands ' 4 ' were generated by the primer OPA9. The percentage for polymorphism ranged from $87.50 \%$ OPA 7 to $57.14 \%$ OPA9.The average polymorphism generated by these two primers was $73.33 \%$ (Table.1). The results obtained from this study can be useful for the future scientists who want to use different RAPD primers for the genetic study of the local accessions or germplasm. Data of RAPD markers scanned from the seven genotypes with two reproducible primers was used to generate similarity coefficients.

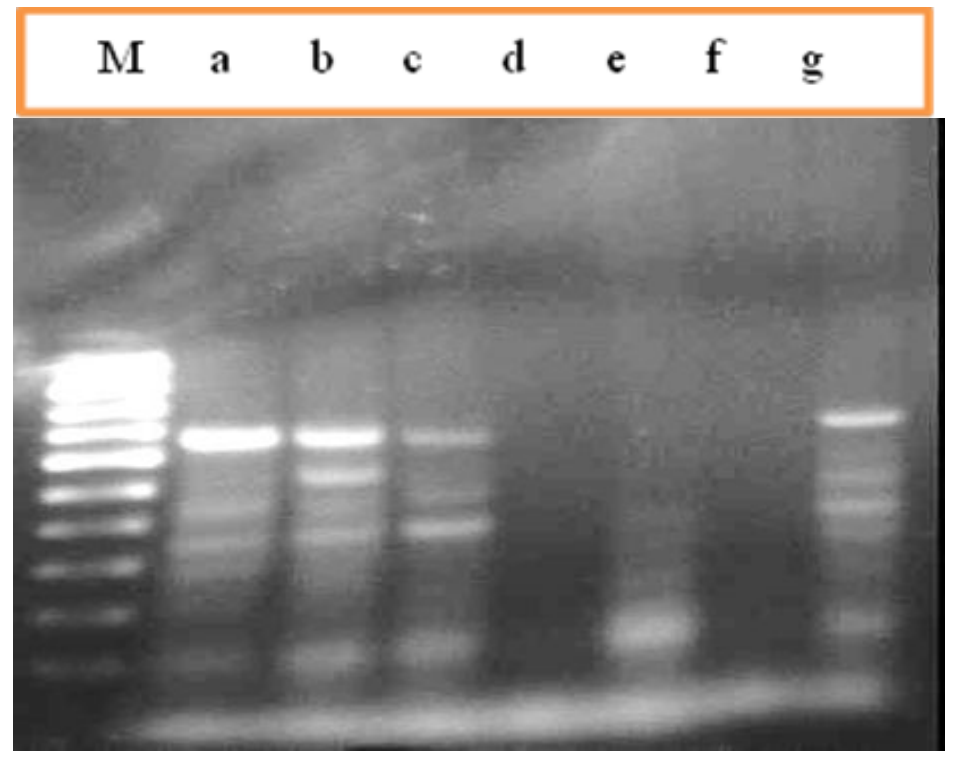

Figure 1: RAPD profiles of seven genotypes of Brassica campestris i.e. a- NRCHB-101, bNRCDR-601, c- PB-80, d- PJK, e- RH-37, f- RH-80 and g- F-59 generated through arbitrary decamer primer OPA 7 


\section{INTERNATIONAL JOURNAL OF RESEARCH -GRANTHAALAYAH \\ A knowledge Repository}

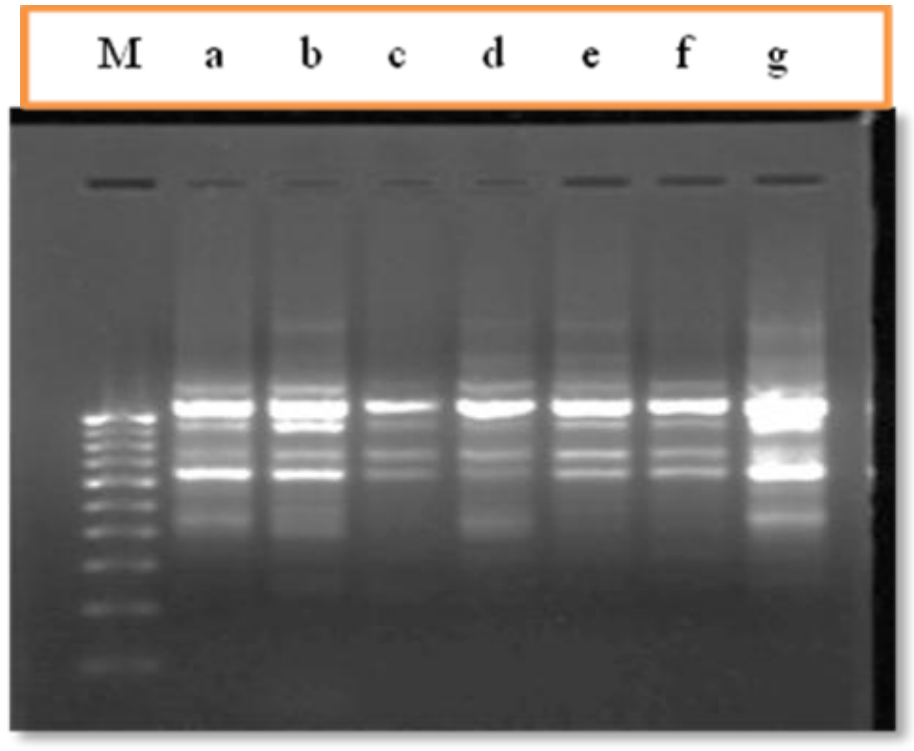

Figure 2: RAPD profiles of seven genotypes of Brassica campestris i.e. a- NRCHB-101, bNRCDR-601, c- PB-80, d- PJK, e- RH-37, f- RH-80 and g- F-59 generated through arbitrary decamer primer OPA 9

Table 1: Summary of the bands revealed from two primers based on RAPD band analysis

\begin{tabular}{|l|l|l|l|l|}
\hline \multirow{2}{*}{ Primers } & Sequences & \multirow{2}{*}{$\begin{array}{l}\text { Total No. of } \\
\text { bands (a) }\end{array}$} & $\begin{array}{l}\text { Total No. of } \\
\text { polymorphic bands }\end{array}$ & Polymorphism \\
\cline { 2 - 6 } & $(\mathbf{5}, \mathbf{3})$ & $(\mathbf{b})$ & 7 & 87.50 \\
\hline OPA 7 & GAAACGGGTC & 8 & 4 & 57.14 \\
\hline OPA 9 & GGGTAACGCC & 7 & $\mathbf{b}$ 100) \\
\hline Total & & $\mathbf{1 5}$ & $\mathbf{1 1}$ & $\mathbf{7 3 . 3 3}$ \\
\hline
\end{tabular}

A maximum similarity based on Jaccard coefficient was showed highest and lowest value (0.750) and (0.364) respectively. Lowest value was found only in one pair of individual (PB80and PJK) that considered genetically most diverse while two pairs of individuals (NRCHB101 and PB-80) and (RH-37 and RH-80) showed highest value of this Jaccard genetic similarity (Table 2). The genetic distance among individuals of Brassica campestris was found highest 0.636 and the lowest genetic distance $(0.250)$ was recorded. Highest value was found only in one pair of individual (PB-80 and PJK) while two pairs of individuals showed lowest value (NRCHB-101 and PB-80) and (RH-37 and RH-80) of genetic distance (Table 3). 
Table 2: Genetic similarity based on Jaccard coefficient among individuals of Brassica campestris

\begin{tabular}{|l|l|l|l|l|l|l|l|}
\hline & $\begin{array}{l}\text { NRCHB } \\
-101\end{array}$ & $\begin{array}{l}\text { NRCDR } \\
-601\end{array}$ & PB-80 & PJK & RH-37 & RH-80 & F-59 \\
\hline $\begin{array}{l}\text { NRCHB- } \\
101\end{array}$ & - & 0.643 & 0.750 & 0.500 & 0.538 & 0.500 & 0.733 \\
\hline $\begin{array}{l}\text { NRCDR- } \\
601\end{array}$ & & - & 0.667 & 0.417 & 0.727 & 0.545 & 0.667 \\
\hline PB-80 & & & - & 0.364 & 0.545 & 0.500 & 0.533 \\
\hline PJK & & & & - & 0.556 & 0.714 & 0.429 \\
\hline RH-37 & & & & & - & 0.750 & 0.571 \\
\hline RH-80 & & & & & & - & 0.429 \\
\hline F-59 & & & & & & & - \\
\hline
\end{tabular}

Table 3: Genetic distance among individuals of Brassica campestris

\begin{tabular}{|l|l|l|l|l|l|l|l|}
\hline & $\begin{array}{l}\text { NRCHB } \\
-101\end{array}$ & $\begin{array}{l}\text { NRCDR } \\
-601\end{array}$ & PB-80 & PJK & RH-37 & RH-80 & F-59 \\
\hline $\begin{array}{l}\text { NRCHB- } \\
101\end{array}$ & - & 0.357 & 0.250 & 0.500 & 0.462 & 0.500 & 0.267 \\
\hline $\begin{array}{l}\text { NRCDR- } \\
601\end{array}$ & & - & 0.333 & 0.583 & 0.273 & 0.455 & 0.333 \\
\hline PB-80 & & & - & 0.636 & 0.455 & 0.500 & 0.467 \\
\hline PJK & & & & - & 0.444 & 0.286 & 0.571 \\
\hline RH-37 & & & & & - & 0.250 & 0.429 \\
\hline RH-80 & & & & & & - & 0.571 \\
\hline F-59 & & & & & & & - \\
\hline
\end{tabular}

Cluster analysis based was also done to resolve the phylogenetic relationships among experimental individuals of Brassica campestris. The dendrogram constructed on the basis of Jaccard's coefficient, followed by UPGMA based clustering analysis showed that the genotypes were grouped into three major group viz., group I, group II and group III representing seven cultivars of Brassica campestris (Figure.3). UPGMA clustering system generated three main cluster groups in total through OPA 7 and OPA9 primers. In first main cluster group, it was subdivided further into three sub groups. In first sub group, two genotypes i.e. NRCHB-101 and PB-80 were present, in second sub group contained NRCDR-601 and PJK genotypes and genotype RH-37 lies in third sub group was found to be quite divergent and did not fall in any of the major clusters. While second and third main clusters contained only one genotype i.e. RH-80 and F-59 each respectively. Both of these two groups found divergent enough that to be 


\section{INTERNATIONAL JOURNAL OF RESEARCH -GRANTHAALAYAH \\ A knowledge Repository}

Science

considered distinguishable accessions. (Figure.3).Comparatively higher linkage distance was observed between all other individual's pair. Linkage distances across steps were obtained with the increase starting from step 1 to step 6. Initially, distances were found to be at linkage distance ' 1.4 ' at step 1, and then at other step 2, it increased comparatively to be more than '1.6' linkage distance. At step 4, distance was observed increased to more than ' 2 ' linkage distance. In the step 5 , distance was found to be at between '2.2' and '2.4' linkage distance points and last distance was recorded more than ' 2.4 ' at step 6.It showed comparatively higher distances for all individuals (Figure.4). Means and Standard Deviations (new.sta) for seven genotypes of Brassica campestris were calculated (Table.4). Present results showed that significant diversity exists among the accession and this information could be used in the breeding programmes for other purposes. These results also proved that RAPD markers are highly suitable and efficient tool for genetic characterization of many plant species including oilseed rape and other species [15].

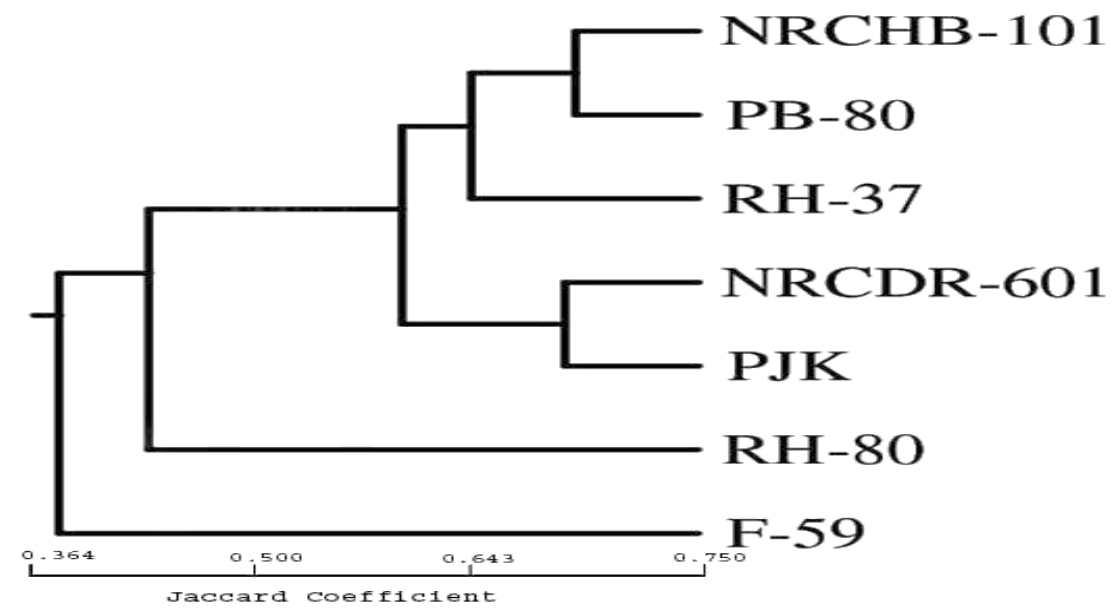

Figure 3: UPGMA cluster analysis showing the diversity and relationship among 7 genotypes of Brassicacampestris based on two RAPD markers

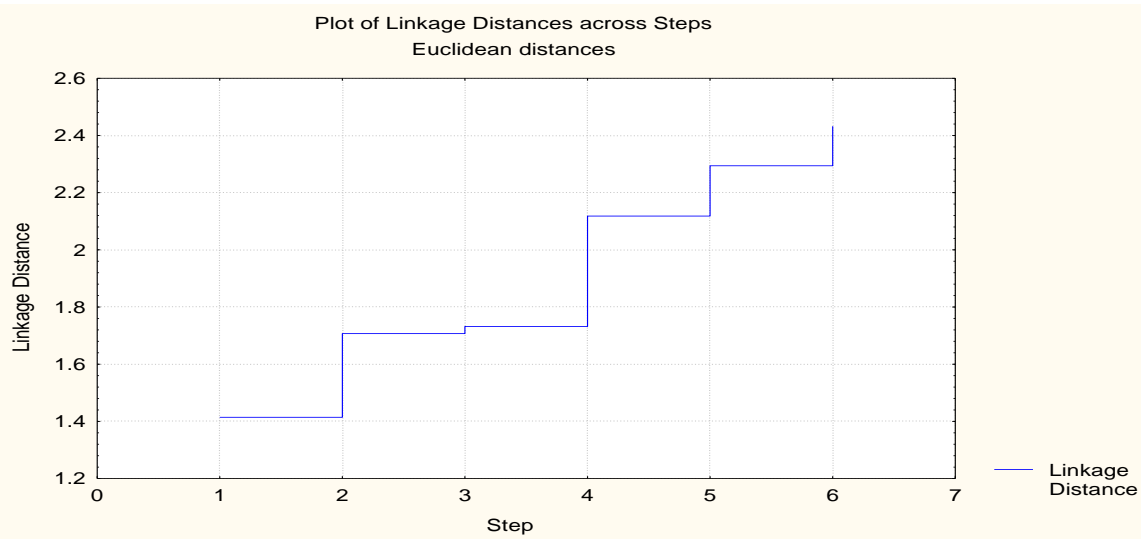

Figure 4: Plot of Linkage Distances across steps for seven genotypes of Brassica campestris through primers OPA7 and OPA 


\section{INTERNATIONAL JOURNAL OF RESEARCH -GRANTHAALAYAH \\ A knowledge Repository}

Science

Table 4: Calculation of Means and Standard Deviations (new.sta) for seven genotypes of Brassica campestris

\begin{tabular}{|l|l|l|}
\hline & mean & st. dev. \\
\hline NRCHB-101 & 0.800000 & 0.414039 \\
\hline NRCDR-601 & 0.733333 & 0.457738 \\
\hline PB-80 & 0.600000 & 0.507093 \\
\hline PJK & 0.400000 & 0.507093 \\
\hline RH-37 & 0.533333 & 0.516398 \\
\hline RH-80 & 0.400000 & 0.507093 \\
\hline F-59 & 0.933333 & 0.258199 \\
\hline
\end{tabular}

\section{CONCLUSIONS}

Extensive breeding process is causing to decrease the genetic diversity in germplasm of crop species. Therefore, germplasm of crop species, such as Brassica campestris should be examined and the genotypes, which have higher genetic diversity index, should be determined and used as potential parental cross material in breeding programs. Analysis by RAPD markers proved to be a useful tool in assessing the genetic diversity of different species of Brassica. RAPD markers are also proved to be highly suitable and efficient tool for genetic characterization of many plant species including oilseed rape and other species.

\section{ACKNOWLEDGEMENTS}

We are thankful to Shiveta Sharma for providing critical reviews of the manuscript and providing helpful comments and suggestions.

\section{REFERENCES}

[1] PrakashS, Hinta K. Taxonomy, cytogenetic and origin of crop Brassica,Opera Bot. 1980, 55: $1-57$.

[2]Toxeopus H, Oost EH, Reuling G. Current aspects of the taxonomy of cultivated Brassica species and use of B. rapa L. versus B. campestris $L$. and a proposal for a new intraspecific classification of B. rapa L. Crucifer Newsletter. 1984, 9: 55-57.

[3] Winter P, Kohl G. Molecular marker technologies for plant improvement. World J MicrobBiot.1995, 11: 438-448.

[4] Mullis KB, Faloona FA, Scharf SJ, Saiki SK, Horn GT, Erlich HA. Specific enzymatic amplification of DNA in vitro: the polymerase chain reaction. Cold Spring Harbor Symp Quant Biol. 1986; 51: 263-273.

[5] Welsh J, McClelland M. Fingerprinting genomes using PCR with arbitrary primers. Nucleic Acids Res. 1990; 18 (24): 7213-7218. 


\section{INTERNATIONAL JOURNAL OF RESEARCH -GRANTHAALAYAH \\ A knowledge Repository}

Science

[6] Ayad WG, Hodking A, Jaradat A and Rao VR.Molecular genetic techniques for plant genetic resources.IPGRI Workshop: Rome, Italy. 1995, 9-11.

[7] Agarwal M, Shrivastava N,Padh H. Advances in molecular marker techniques and their application in plant sciences. Plant Cell Rep. 2008, 27: 617-631.

[8] Pervaiz, ZH, Rabbani MA, Shinwari ZK, Masood MS,Malik SA. Assessment of genetic variability in rice (Oryza sativa L.) germplasm from Pakistan using RAPD markers. Pak. J. Bot. 2010, 42: 3369-3376.

[9] Paterson AH, Damon S,Hewitt JD, Zamir D, Rabino VHD, Lincoln SE, Lander SS, Tanksley SD. Mendelian factors underlying quantitative traits in tomato: Comparison across species, generations and environments. Genetics.1991, 127: 181-197.

[10] Rabbani MA, Masood MS, Shinwari ZK, Yamaguchi-Shinozaki K. Genetic analysis of basmati and non-basmati Pakistani rice (Oryza sativa L.) cultivars using microsatellite markers. Pak. J. Bot. 2010, 42: 2551-2564.

[11] Ren JR, Mcferson LR, Kresovich S, Lamboy WF. Identities and relationship among Chinese vegetable Brassicas as determined by random amplified polymorphic DNA markers. J. Am. Soc. Hort. Sci. 1995, 120: 548-555.

[12] An X, Chen BY, Fu TD, Liu LH. Genetic diversity analysis among Chinese landraces in Brassica juncea using RAPD markers.10th International Rapeseed Congress, Canberra, Australia, 2000

[13] Doyle JJ and Doyle JL. Isolation of plant DNA from fresh tissue. Focus. 1990, 12: 13-15. [14] Rohlf FJ.Numerical taxonomy and multivariate analysis system. New York: Exeter Software Setauket, NTSYS pc 2.02, 1998.

[15] Hu J, Li G, Struss D, Quiros CF. SCAR and RAPD markers associated with 18-carbon fattyacidsin rape seed, Brassicanapus. Plant Breed.1999, 118: 145-150. 